\title{
A Circular Economy Approach to Military Munitions: Valorization of Energetic Material from Ammunition Disposal through Incorporation in Civil Explosives
}

\author{
Carlos Ferreira $^{1} \mathbb{D}$, José Ribeiro ${ }^{1} \mathbb{D}$, Roland $^{\text {Clift }^{2}}$ and Fausto Freire $^{1, * \mathbb{D}}$ \\ 1 ADAI-LAETA, Department of Mechanical Engineering, University of Coimbra, 3030-788 Coimbra, Portugal; \\ carlos.ferreira@dem.uc.pt (C.F.); jose.baranda@dem.uc.pt (J.R.) \\ 2 Centre for Environment and Sustainability, University of Surrey, Guildford, Surrey GU2 7XH, UK; \\ r.clift@surrey.ac.uk \\ * Correspondence: fausto.freire@dem.uc.pt; Tel.: +351-239-790-739
}

Received: 15 October 2018; Accepted: 27 December 2018; Published: 7 January 2019

\begin{abstract}
Ammunition that has reached its end of life or become obsolete is considered hazardous waste due to the energetic material content that must be decommissioned. One of the technologies to dispose of ammunition involves the use of incinerators with sophisticated gas treatment systems; however, this disposal process has important limitations in terms of incinerator capacity, energy requirements and high costs. This article assesses the potential primary energy avoided and environmental benefits arising from the valorization of energetic material from military ammunition by incorporating it into civil emulsion explosives, as an alternative to destructive disposal. This approach follows the circular economy principle, as articulated inter alia in BS 8001:2007, by giving a new service to a residue through its incorporation into a new product. A prospective life-cycle model is implemented based on primary data from previous studies on the conventional disposal process and on the production of emulsion explosive. The model applies system expansion to calculate the environmental burdens avoided when energetic material from ammunition is incorporated into civil explosives. The results show that re-using ammunition through valorization of energetic material greatly reduces the environmental impacts in all categories compared to the conventional disposal process. The benefits arise mainly from avoiding the incineration and flue gas treatment processes in ammunition disposal, and displacing production of civil explosive components with the energetic material from ammunition.
\end{abstract}

Keywords: ammunition incineration; down-cycling; energetic material recycling; industrial ecology; life-cycle assessment

\section{Introduction}

Armed Forces possess significant quantities of military munitions that need to be disposed of when they reach their end-of-life or become obsolete. Energetic materials such as propellants and explosives, which are complex and expensive chemical substances, are regularly sent for disposal when the ammunition in which they are contained is decommissioned. The exact quantity of munitions that need to be disposed of is difficult to ascertain. Since 2008, NSPA (NATO Support and Procurement Agency) have awarded 39 demilitarization contracts for disposal of munitions that amounted to a total of approximately 400 million euros [1]. The stockpile of munitions to be decommissioned in the United States in 2010 has been estimated to as 450,000 metric tons [2]. Other parts of the world also have significant amounts of munitions for disposal which, in addition to safety hazards, present a security problem due to the potential for use in terrorist activities [3]. 
In Portugal, the disposal of munitions has been an important issue due to the significant stock of obsolete munitions, which usually have to be stored for long periods of time before being incinerated in small batches in plant with limited capacity [4]. The disposal of munitions is carried out by the company idD, which decommissions approximately 550 metric tons of munitions per year, of which 80 metric tons are energetic material [4]. The problem of munitions disposal is not unique to Portugal so that, although the results presented here refer to Portugal, the conclusions are general.

Disposal of ammunition needs to be carried out under secure conditions and with minimum environmental impact, which makes it an onerous process with costs estimated as approximately 1600 USD per metric ton of munition [5]. Currently, most of the energetic material discharged from ammunition is disposed of in incinerators with gas treatment systems. However, use of such combined elimination systems is limited by the available capacity, energy requirements and costs of operation and maintenance. Ferreira et al. [6] assessed the environmental impacts of the disposal process in Portugal and demonstrated significant burdens associated with incineration and gas treatment, primarily due to high consumption of electricity and propane.

The energetic material in obsolete ammunition is frequently in usable condition with significant value. However, direct re-use for military purposes is not viable due to highly demanding safety standards and the resultant high costs of re-use. Therefore, instead of consuming energy to destroy the material, at least some of its value should be recovered by down-cycling into other uses. The solution explored here is based on incorporating energetic material into ammonium nitrate-based emulsion explosives (a common type of civil explosive used for mining and construction). This approach would not only avoid incineration and its inherent environmental impacts but would also reduce the impacts associated with production of the civil explosive by partial displacement of the emulsion matrix components. As this process entails down-cycling a residue into a new product to provide a new function, it follows the circular economy principle, for example as articulated in BS 8001 [7].

Previous experimental work has shown the feasibility of blending energetic material (powders and TNT) into ammonium nitrate (AN) based emulsion explosives. Ribeiro et al. [8] studied the behavior of emulsion explosives incorporating different types of energetic materials (e.g., single and double based powders, and TNT) and concluded that up to $20 \% w / w$ of any of these materials can be incorporated without forming any new chemical species. This indicates a good range of chemical compatibility between the emulsion explosive and energetic materials from munitions. However, these amounts of energetic material caused a slight increase in the detonation velocity and in the shock sensitivity. These changes can be reduced to an acceptable level, and eventually removed completely, by reducing the energetic material content sufficiently. Ribeiro et al. [8] also demonstrated that a simple processing technique such as grinding is necessary, but sufficient, to allow the incorporation of the energetic materials in the emulsion explosive matrix. The potential advantages of recycling energetic materials have been highlighted [9], but there appears to be no published work that has attempted to quantify the environmental benefits of down-cycling the energetic material into other uses. Down-cycling of energetic material is currently carried out by companies that have contracts for both elimination of munitions and production of civil explosives. However, for companies that just focus on one of these businesses, there are barriers to adopting this approach, particularly in countries where the quantities of munitions demilitarized are small. Production of civil explosive incorporating down-cycled energetic material requires supplementary quality control. It may not be economically attractive to develop a new market centered on the production of a new type of civil explosive unless enough energetic material is available. This limitation could hinder development of a circular economy in energetic material from munitions.

The main goal of this article is to calculate the potential primary energy use avoided and environmental benefits arising from the incorporation of energetic material from military ammunition into ammonium nitrate-based emulsion explosives, as an alternative to conventional ammunition disposal. The assessment allows for displacement of both incineration of the energetic materials and production of the equivalent matrix components of an emulsion explosive, using system expansion 
to avoid allocation by assigning the avoided environmental burdens to the function of managing the military explosive.

\section{Materials and Methods}

In this section, the life-cycle model and the inventory developed for both the conventional process and the proposed closed-loop process are described. First, the current approach to disposal of military ammunition is presented. The prospective LCA is then set out, covering recycling of the energetic material including production of civil explosives, using system expansion to avoid allocation across the multiple functions. The life-cycle model, the life-cycle inventory, and the calculation of the life-cycle impacts were conducted using the Simapro 8.0 software [10]. As in other LCA studies, a number of assumptions and simplifications were necessary; in this study, they were required due to the lack of available data for the novel recycling processes (e.g., electricity consumption for grinding the recycled energetic material, and for mixing it into the emulsion explosive product). Another limitation is the static nature of the LCA: Changes such as technological evolution and introduction of new materials have not been considered.

\subsection{Conventional Decommissioning of Military Ammunition}

Figure 1 shows a simplified flowchart of the conventional process to dispose of military ammunition, including information associated with inputs and outputs. Disposal of military ammunition encompasses:

(i) dismantling of ammunition to separate the different components (e.g., cartridge, projectile, fuse);

(ii) energetic material unloading in which powders and high explosives are withdrawn from the cartridge and the warhead;

(iii) separation of inert materials (e.g., metals, plastics, electronics) from the ammunition components;

(iv) incineration of the energetic materials in a static kiln; and

(v) treatment of the gases resulting from the incineration.

The Life-Cycle Inventory (LCI) was implemented based on detailed data from idD, the company responsible for ammunition disposal in Portugal. This inventory is also representative of the typical disposal of energetic material in other countries. It includes the impacts associated with generating the energy consumed (electricity and propane), supplying water and chemicals for the gas treatment process, and the emissions associated with combustion (or thermal degradation) of the energetic materials as well as combustion of the propane in a post-combustion chamber. Unusually for LCA, manufacture and transport of equipment was also included in the inventory (information provided by $\mathrm{idD}$ ) as the incineration is an intensive batch process with limited equipment service life. The functional unit was defined as $1 \mathrm{~kg}$ of TNT equivalent of energetic material disposed. More detailed information and analysis of this process are given in Ferreira et al. [6]. 
Decommissioning of military ammunition

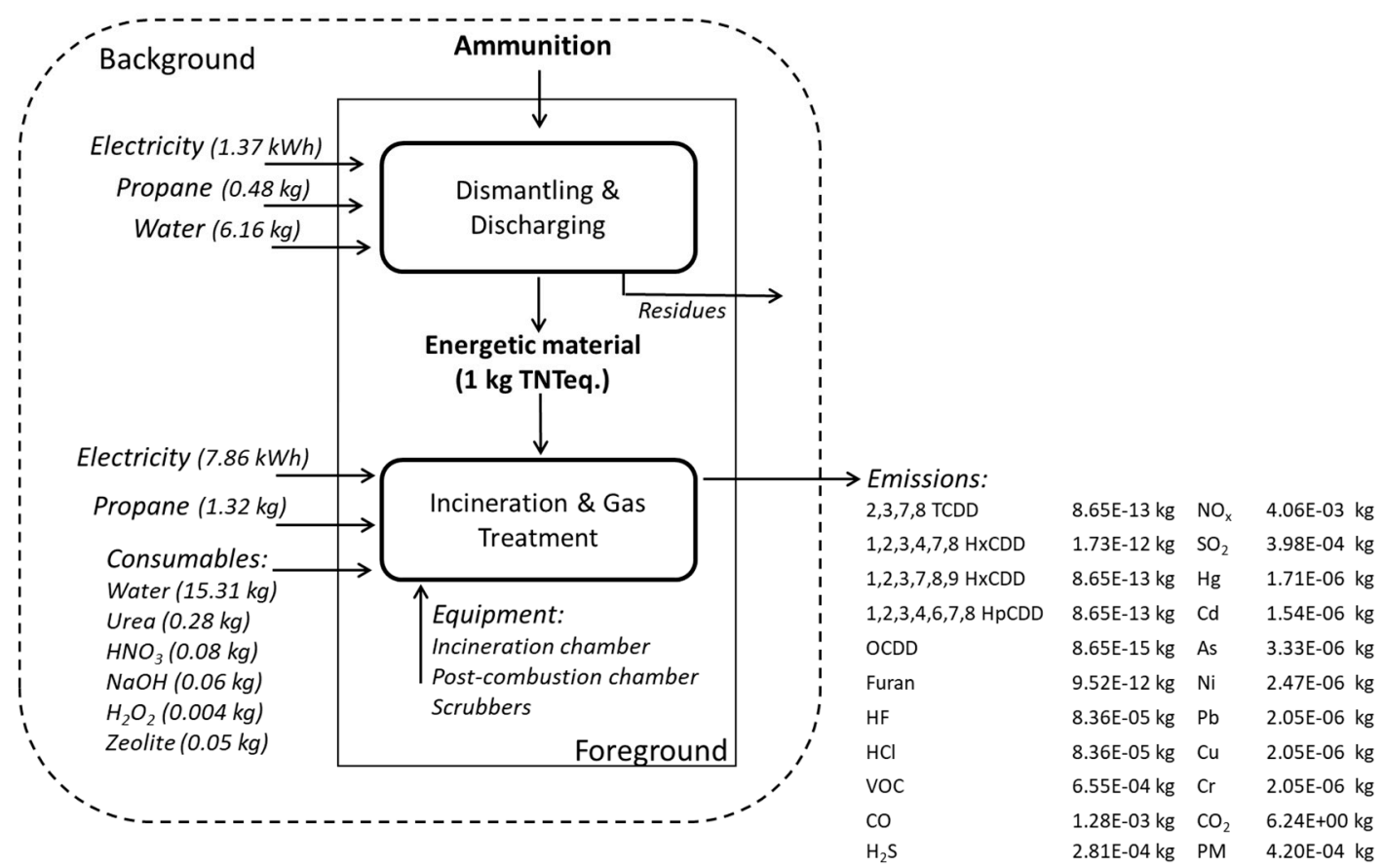

Figure 1. Simplified flowchart for conventional disposal of $1 \mathrm{~kg}$ TNTeq of energetic material from military ammunition.

\subsection{Recycling Energetic Material}

Figure 2 shows the flowchart for a possible process to dispose of explosives in ammunition by recycling (more strictly, down-cycling) into emulsion explosives, including information associated with the main inputs and outputs. This process includes dismantling (carried out as described above for conventional disposal) to separate the different ammunition components and unload the energetic material. Dismantling generates a range of energetic materials, in different forms (e.g., prills, sticks, particles and flakes), so it is necessary to grind each of these materials and blend them to yield a consistent final product that can be incorporated into the emulsion explosive. An energy consumption of $0.9 \mathrm{kWh}$ per $\mathrm{kg}$ TNT equivalent for the grinding process is estimated, based on the power of the grinder and the grinding time. It is assumed, based on primary evidence, that material losses in grinding and incorporating the energetic material in the emulsion explosive are negligible. The use phase of the emulsion explosive is not included in the analysis, because once the energetic material has been incorporated in the emulsion explosive its life-cycle no longer differs from the base case (the standard emulsion explosive) with which it is compared. It should be noted that the proportion of down-cycled material $(<20 \%)$ added to the standard emulsion is small and does not influence the performance of the civil explosive. Information on the life-cycle impacts associated with the production of civil explosives is needed to assess the impacts avoided by down-cycling the energetic material. LCI data for conventional production of the emulsion explosive are taken from Ferreira et al. [11], covering transport of raw material, emulsification, sensitization and packaging, based on detailed process data provided by a European company. The constituents of the emulsion matrix were ammonium nitrate, water, mineral oil and an emulsifier (Polycarboxylate), together with hollow microspheres of extruded polystyrene (XPS) included as a sensitizing agent. The energy used in the process-electricity and light fuel oil-was also included in the inventory.

The ground energetic material is incorporated into the emulsion matrix, displacing an equivalent amount of ammonium nitrate, mineral oil and emulsifier, before the resulting mixture is sensitized by adding hollow polymer microspheres. Due to lack of data for this specific operation, 
the energy consumption in producing the mixed emulsion was assumed to be equal to that for the conventional process.

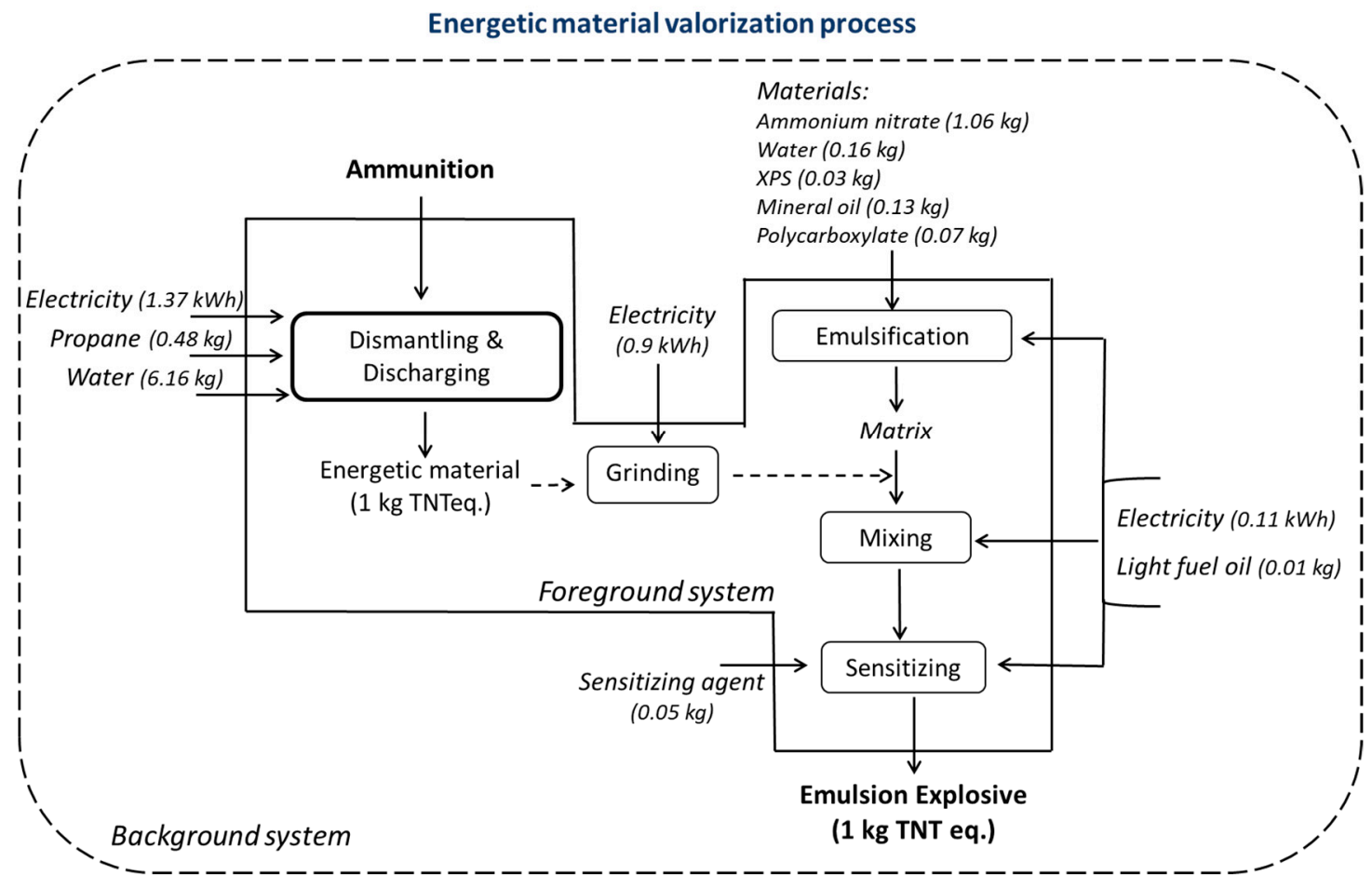

Figure 2. Simplified flowchart for valorization of $1 \mathrm{~kg}$ TNTeq of energetic material by incorporation into civil explosive.

Incorporation of the energetic material from military ammunition into civil explosives is a possible way to valorize a waste that otherwise would be incinerated with significant energy consumption and environmental impacts. This constitutes a multifunctional process. The primary function is still to dispose of military ammunition, so the functional unit is defined as disposal of $1 \mathrm{~kg}$ of TNT equivalent of energetic material from ammunition. However, the process also provides the function of producing $1 \mathrm{~kg}$ of TNT equivalent of emulsion explosive. The multifunctionality is handled according to the approach recommended in ISO 14040 [12], following common practice for recycling and down-cycling of pre-existing waste (e.g., [13-17]): System expansion is used to avoid allocation by including the extra function, i.e., production of $1 \mathrm{~kg}$ of TNT equivalent of civil explosive $[18,19]$.

Expanding the system in this way accounts for the two modifications to the conventional ammunition disposal process, as shown in Figure 3: (i) avoiding the incineration and flue gas treatment process associated with the ammunition disposal; and (ii) displacing production of emulsion explosive matrix. The environmental advantages of down-cycling rather than disposal are then represented by:

Avoiding incineration and gas cleaning

Displacing production of emulsion explosive

Grinding energetic material from military ammunition. 
Energetic material valorization process

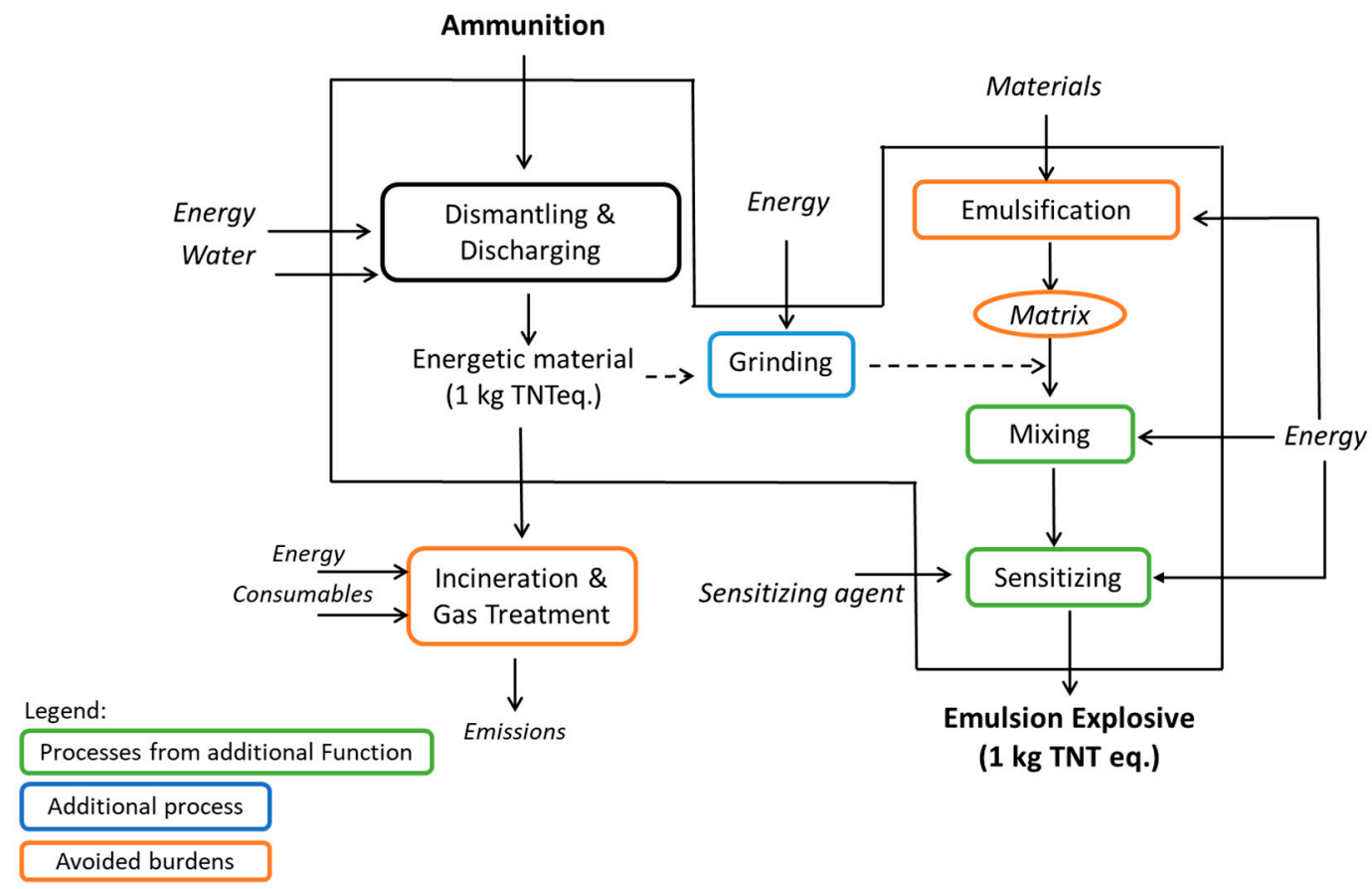

Figure 3. Simplified flowchart to show the additional functions and avoided burdens associated with recycling of $1 \mathrm{~kg}$ TNTeq of energetic material by incorporation into civil explosive.

\subsection{Life-Cycle Impact Assessment Methods}

Life-cycle impact assessment provides additional information by converting the inputs and outputs comprising the inventory data into quantified potential environmental impacts [20] using characterization factors for specific impact categories. Two general approaches to impact characterization have been developed: Problem-oriented (mid-point categories) or damage-oriented (end-point categories) [21]. For this study, the mid-point approach was used as the results have the advantage of lower uncertainty associated with the cause-effect chain between the inventory and the potential impacts compared to end-points. For this assessment, the CML problem-oriented method was employed, because it is widely accepted as a reliable way to assess the impacts and also because previous studies to evaluate the impacts of demilitarization of ammunition [6] and production of civil explosive [11] also employed this method. The six environmental impact categories selected as most significant here are summarized in Table 1 [22]. In addition to the environmental impacts in Table 1 , one category for the non-renewable primary energy and three toxicological impact categories (human toxicity with cancer and non-cancer effects, and ecotoxicity) have been considered. The non-renewable primary energy was calculated by the CED (cumulative energy demand) method [22]. The toxicological impacts were estimated using the USEtox model for the cause-effect chain. Two sets of characterization factors are available: 'recommended' factors derived from the most widely used version of USEtox; and 'interim' factors derived from a version of USEtox modified with the aim of providing a better description of the cause-effect chain for metals, amphiphilic, and ionic substances. This work is based on the 'recommended' characterization factors because they are more widely used, pending assessment of the reliability of the 'interim' factors [23]. 
Table 1. Description of impacts considered: Non-renewable primary energy use (CED method), six environmental impact categories (CML method) and three toxicological impact categories (USEtox method), adapted from [22].

\begin{tabular}{|c|c|c|}
\hline Impact Category & Description & Unit \\
\hline $\begin{array}{l}\text { Non-renewable Primary } \\
\text { Energy }\end{array}$ & Primary energy considering various energy sources & MJ prim. \\
\hline Abiotic Depletion (AD) & $\begin{array}{l}\text { Determine the extraction of minerals and fossil fuels, based } \\
\text { on concentration of reserves and rate of de-accumulation }\end{array}$ & $\mathrm{kg} \mathrm{Sb} \mathrm{eq}$ \\
\hline Acidification (Acid) & Describes the fate and deposition of acidifying substances & $\mathrm{kg} \mathrm{SO}_{2} \mathrm{eq}$ \\
\hline Eutrophication (Eut) & $\begin{array}{l}\text { Describes the impacts due to excessive levels of } \\
\text { macronutrients in the aquatic environment }\end{array}$ & $\mathrm{kg} \mathrm{PO}_{4}{ }^{3-} \mathrm{eq}$ \\
\hline Global Warming (GW) & $\begin{array}{l}\text { Describes the impacts associated with emissions of } \\
\text { greenhouse gases }\end{array}$ & $\mathrm{kg} \mathrm{CO}_{2} \mathrm{eq}$ \\
\hline $\begin{array}{l}\text { Ozone Layer Depletion } \\
\text { (OLD) }\end{array}$ & $\begin{array}{l}\text { Defines the impacts from the emission of gases that have an } \\
\text { effect in the destruction of the stratospheric ozone layer }\end{array}$ & kg CFC-11 eq \\
\hline $\begin{array}{l}\text { Photochemical Oxidation } \\
\text { (OP) }\end{array}$ & Describes the creation of reactive substances (mainly ozone) & $\mathrm{kg} \mathrm{C}_{2} \mathrm{H}_{4} \mathrm{eq}$ \\
\hline $\begin{array}{l}\text { Human Toxicity Cancer } \\
\text { (HT, cancer) }\end{array}$ & $\begin{array}{l}\text { Describes the cancer effects of chemical emissions on } \\
\text { human health }\end{array}$ & cases \\
\hline $\begin{array}{l}\text { Human Toxicity Non-cancer } \\
\text { (HT, non-cancer) }\end{array}$ & $\begin{array}{l}\text { Describes the non-cancer effects of chemical emissions on } \\
\text { human health }\end{array}$ & cases \\
\hline Ecotoxicity & Describes the effects of chemicals on ecosystems & PAF.m³.day \\
\hline
\end{tabular}

Normalization is an optional further step in which the estimated life-cycle impacts of a product or service are expressed as fractions of the impacts associated with a reference activity or situation [24]. The normalized values show the relative significance of the different mid-point impacts [20]. In this work, the environmental impacts were normalized with respect to the total impact of the EU25+3 economy for the year 2000 [25]. Details of the normalization process and normalized results are given in the Appendix A (Figures A1 and A2).

\section{Results and Discussion}

\subsection{Life-Cycle Impact Results}

Life-Cycle Impact Assessment results associated with the recycling of the energetic material are presented in this section. The full comparison between the impacts for conventional ammunition disposal by incineration and valorization of energetic material is reported in Figure 4. Comparison between the two approaches shows that down-cycling energetic material from munitions significantly decreases all impacts; the main benefits arise from avoiding incineration and gas cleaning for the conventional process, and also transport and production of the emulsion explosive matrix. The grinding process, an operation specific to the new approach, presents a nugatory contribution to the life-cycle impacts in all categories.

The normalized results help in selecting the most important impact categories, to facilitate analysis of the potential benefits of recycling energetic material into civil explosives. The most significant environmental impact categories emerge as Eutrophication, Acidification, and Global Warming; while the most significant toxicological impact category is Human Toxicity with cancer effects. The following discussion is presented in terms of these four impact categories but, for the particular case assessed here, the overall conclusions are also supported by the other environmental and toxicological impacts. 


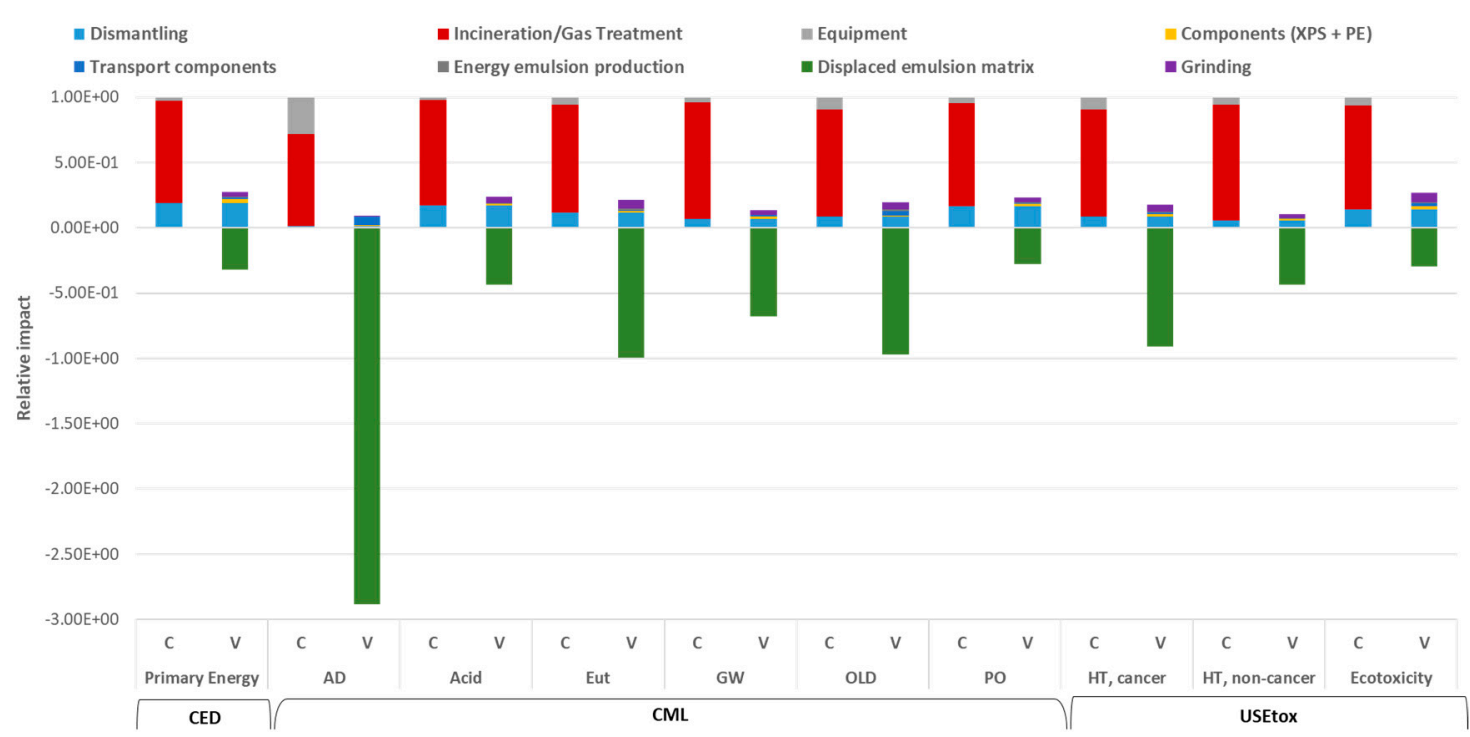

Figure 4. Comparison between the impacts per $\mathrm{kg}$ TNT eq associated with conventional ammunition disposal by incineration $(\mathrm{C})$ and with down-cycling of energetic material from ammunition into civil explosives (V).

Table 2 shows the contributions to the four dominant impact categories of the main processes associated with conventional disposal and down-cycling into civil explosives. Dismantling is common to both processes, along with final use, so the comparison depends on incineration and production of the civil explosives. The impacts for conventional disposal are dominated by the incineration and gas treatment process, mainly due to the electricity required (whose contribution ranges from $35 \%$ of Global Warming to $80 \%$ of Ecotoxicity). Down-cycling of energetic material from munitions avoids these processes, resulting in a decrease of the environmental impacts by approximately $80 \%$. These savings result from the high energy requirement of the incineration and flue gas treatment operations in the conventional disposal process, arising from the need to heat the batch-operated kiln and maintain it at the required temperature $\left(400{ }^{\circ} \mathrm{C}\right.$ to $\left.600^{\circ} \mathrm{C}\right)$ as well as to operate the equipment used in treating the flue gas to ensure acceptably clean emissions (post-combustion chamber, selective catalytic reduction systems, and scrubbers). Moreover, for safety reasons, the static kiln only operates with small batches of energetic material (up to $20 \mathrm{~kg}$ TNT equivalent per hour); this increases its operating time and specific energy consumption.

The impacts avoided by displacing production of the emulsion matrix are also noteworthy. In fact, the avoided burdens associated with the production and transport of the matrix components (principally ammonium nitrate, which alone contributes more than $75 \%$ of the total impact) are similar to or higher than the life-cycle impacts resulting from the dismantling of munitions. Producing the constituent components accounts for more than $80 \%$ of the total impacts for production of emulsion explosive [11], so it is not surprising that the displacement of these components presents a substantial benefit. As a result, the benefits from displacing the emulsion explosive matrix alone are enough to make down-cycling of energetic material from military munitions desirable from an environmental perspective.

As noted above, the additional energy required to grind the energetic material for incorporation into the emulsion explosive matrix is nugatory in comparison with the other impacts: Representing less than $8 \%$ of the total life-cycle impacts. Therefore, the grinding process is not an obstacle to down-cycling of energetic material from military munitions. 
Table 2. Contribution to environmental life-cycle impacts of conventional ammunition disposal and down-cycling of energetic material from ammunition (per kg TNTeq.).

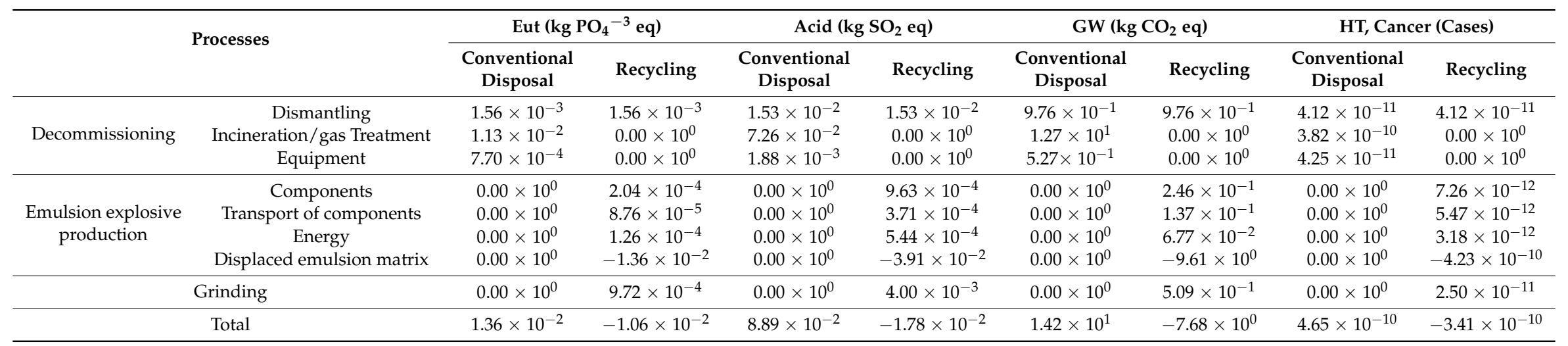




\subsection{Scenario Analysis: Influence of Electricity Mix}

The results summarized above show that the environmental impacts from decommissioning of military explosives depend strongly on the high energy requirements of the incineration and gas treatment processes, and hence on the environmental impacts associated with generation and distribution of electricity. To gauge the generality of the conclusions on the benefits of down-cycling, a comparative assessment was carried out to compare the impacts in Portugal with three other electricity mixes-USA, China and Sweden. The environmental impacts of the electricity mixes considered here are based on data from the year 2008 [26,27]. However, the specific cases are not critical because the purpose of the scenario analysis is to explore a wide spectrum of different energy sources.

Figure 5 compares the impacts for incineration of ammunition in a static kiln using the different electricity mixes for the four dominant impact categories: Acidification, Eutrophication, Global Warming, and Human Toxicity, cancer. As expected, the electricity mixes with high carbon intensity present high impacts, illustrated by the case of China with an electricity mix based predominantly on coal. In fact, for munitions disposal in China, the environmental impacts are greater than for disposal in Portugal across the majority of the impact categories. The electricity mix in Sweden in 2008 was predominantly hydro and nuclear, leading to lower impacts in all environmental categories.

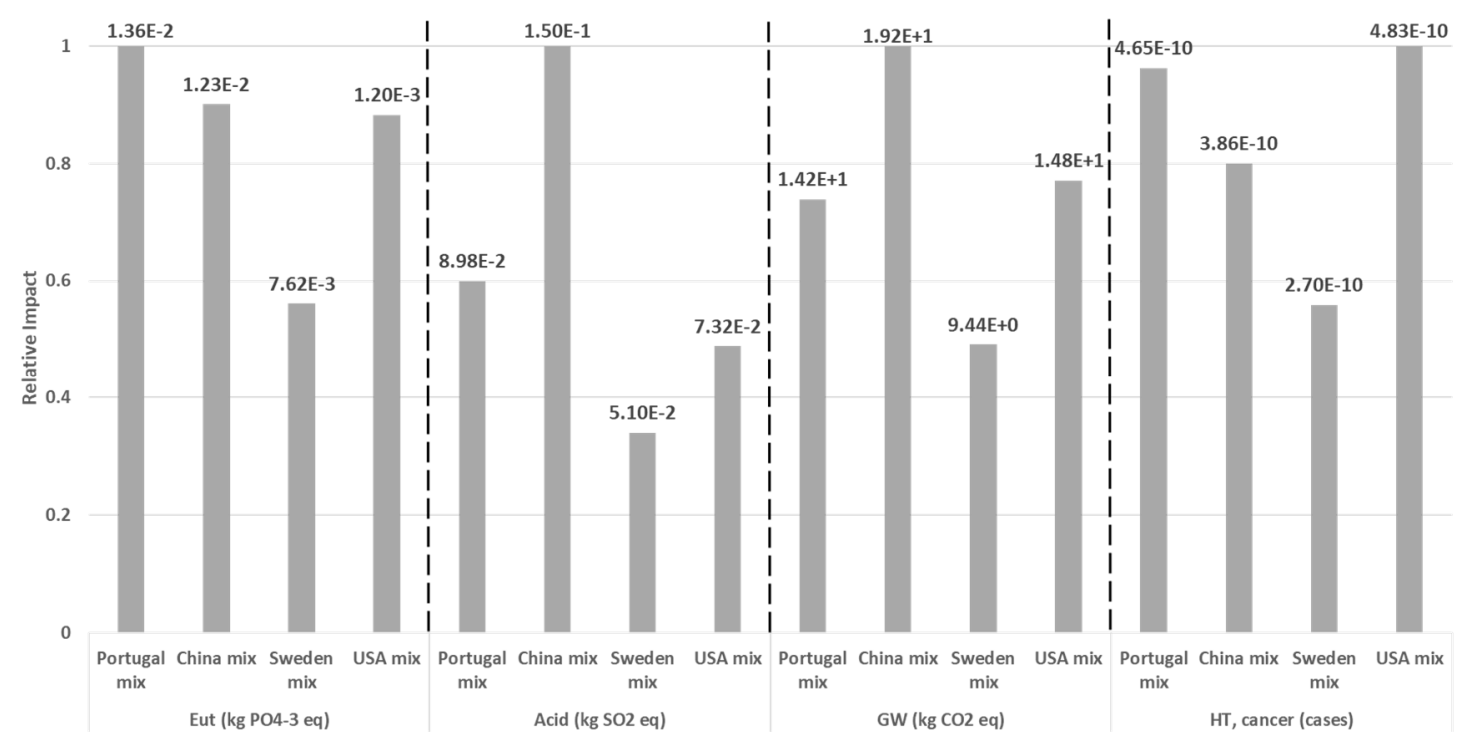

Figure 5. Comparison of impacts associated with the disposal of munitions by incineration in a static kiln considering four different electricity mixes.

These results confirm the benefits from avoiding the impacts from the incineration and gas treatment processes, decreasing the impacts by at least $80 \%$, and also avoiding impacts from production of the emulsion explosive matrix. Even for electricity mixes with low carbon intensity, applying the circular economy approach by down-cycling the energetic material in munitions at end-of-life leads to significant environmental benefits.

\section{Conclusions}

This work has assessed the potential reductions in primary energy use and environmental and toxicological impacts resulting from adopting a circular economy approach to dispose of energetic material from military ammunition by incorporation into civil explosives. System expansion has been employed to account for the avoided burdens.

Down-cycling of energetic material is an alternative to conventional disposal in which the end-of-life energetic material is incinerated in a static kiln with flue gas treatment. Significant environmental improvements result from avoiding the incineration and flue gas treatment operations 
which dominate the impacts associated with conventional disposal. Further significant improvements result from reducing the demand for emulsion explosive matrix, thereby avoiding production and transport of the emulsion explosive matrix components. The overall energy, environmental, and toxicological benefits show conclusively that valorization of the energetic material of military munitions by incorporation into civil explosives is an improved environmental solution whatever the background energy system.

Decommissioning military explosives, in part to ensure that they are not available for terrorist activities, is a world-wide problem. However, the approach recommended here may not be viable in countries with relatively small quantities of redundant munitions, so there appears to be a case for an international initiative to pursue this approach. Furthermore, as this work presents the first analysis of the potential benefits associated with the down-cycling of energetic material from ammunition into new products, future analysis can address the potential advantages from recycling other types of energetic material with the employment of different technologies, or explore applying this approach to other products (e.g., boosters).

Even though there are clear environmental benefits to be had from valorizing energetic material at end-of-life, there are still some barriers to incorporating material from military munitions into civil explosives, mainly due to commercial and technical issues. These represent specific examples of more general problems in implementing the circular economy concept [28]. Companies that produce civil explosives would be compelled to inform their clients that they are buying explosives containing recycled material, possibly leading to some variations in their performance and safety characteristics compared with the standard explosives; this may well meet resistance from the producers. Furthermore, the energetic materials to be incorporated into civil explosives would originate from different types of munition, leading to diverse batches with somewhat different specifications. This will require supplementary quality control methods and possibly changes in the procedures for transport and use of some civil explosives.

Author Contributions: C.F. carried out the LCA modelling, with advice from R.C. and F.F. on the use of system expansion and interpretation of the results. J.R. provided expertise on production and management of explosives. All four authors collaborated in drafting the paper.

Funding: The authors gratefully acknowledge the support from the project ReNATURE-Valorization of the Natural Endogenous Resources of the Centro Region (Centro 2020, Centro-01-0145-FEDER-000007), and the project SAIBIOS co-funded by FEDER and Fundação para a Ciência e Tecnologia (FCT) POCI-01-0145-FEDER-016765 (PTDC/AAG-MAA/6234/2014)

Acknowledgments: The authors would like to thank the advice from the technical group of the European Defence Agency, Category B Ad-Hoc Project ERM (Environmentally Responsible Munitions).

Conflicts of Interest: The authors declare no conflict of interest.

\section{Appendix A}

To facilitate the detailed analysis of the potential benefits of recycling energetic material in civil explosive production, the environmental life-cycle results were normalized to select the most relevant impact categories. The normalization for the environmental impact categories was carried out using the normalization factors provided by the CML method (referred to the total impact of the EU25+3 economy for the year 2000 [25]). Figure A1 shows the normalized results demonstrating that, Acidification, Eutrophication, and Global Warming are the most significant impact categories. 


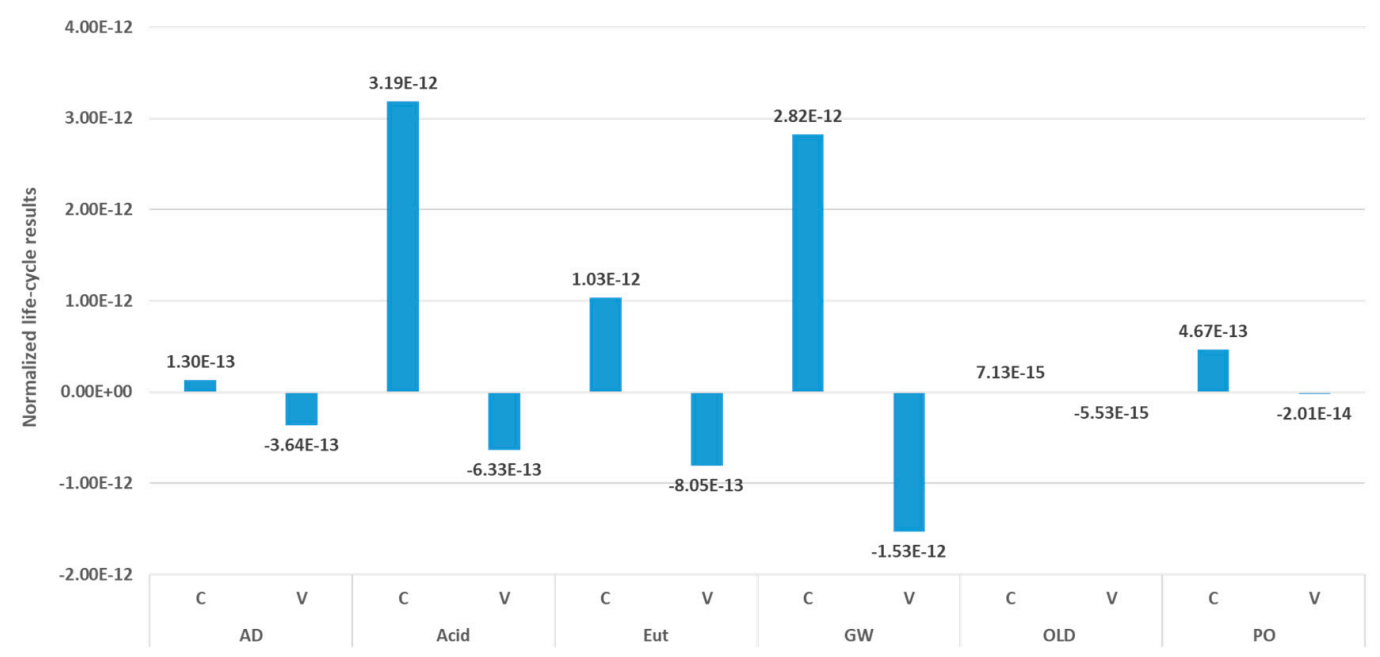

Figure A1. Normalized environmental impacts associated with conventional ammunition disposal by incineration (C), and with down-cycling of energetic material (V) (per kg TNTeq.).

A similar approach was used for normalization of the three toxicological impact categories from the USEtox method, using normalization factors from Benini et al. [29] based on data for emissions in the EU-27 countries for the year 2010. As shown in Figure A2, Human Toxicity with cancer effects emerges as the most significant toxicological impact; the analysis in the results section is therefore presented in terms of the three environmental impact categories noted above and Human Toxicity with cancer effects. It may be noted that the normalization factors for the toxicological effects are associated with much higher uncertainty than those for the other impact categories, as they were calculated using the "recommended" and "interim" impacts. However, the selection of the most significant toxicological impact category, even with a higher uncertainty, will not impact the interpretation of the results.

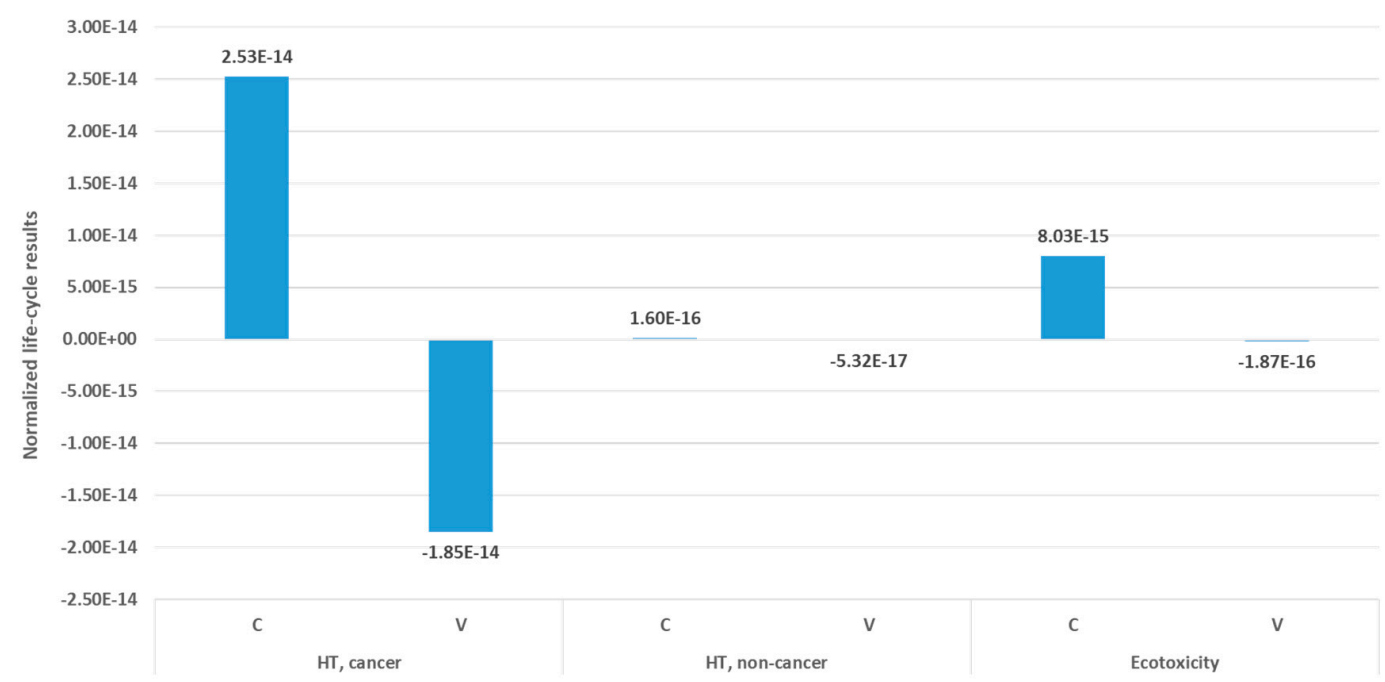

Figure A2. Normalized toxicological impacts associated with conventional ammunition disposal by incineration (C) and with down-cycling of energetic material (V) (per kg TNTeq.).

\section{References}

1. NSPA-NATO Support and Procurement Agency. Available online: https://www.nspa.nato.int/en/ rganization/procurement/contract.htm (accessed on 12 November 2018).

2. Small Arms Survey. Small Arms Survey 2013: Everyday Dangers; Cambridge University Press: Cambridge, UK, 2013; pp. 186-217. 
3. Wilkinson, J.; Watt, D. Review of Demilitarisation and Disposal Techniques for Munitions and Related Materials; MSIAC/NATO/PfP Unclassified Report; Munitions Safety Information Analysis Center: Belgium, Brussels, January 2006; Available online: http:/ / rasrinitiative.org/pdfs/MSIAC-2006.pdf (accessed on 6 March 2018).

4. IdD; Plataforma das Indústrias de Defesa Nacionais, Alcochete, Portugal. Personal Communication, 2018.

5. RTO (Research and Technology Organization). Environmental Impact of Munition and Propellant Disposal: Final Report of Task Group AVT-115; North Atlantic Treaty Organization: Brussels, Belgium, 2010.

6. Ferreira, C.; Ribeiro, J.; Mendes, R.; Freire, F. Life-Cycle Assessment of Ammunition Demilitarization in a Static Kiln. Propellants Explos. Pyrotech. 2013, 38, 296-302. [CrossRef]

7. BS 8001, BS 8001: Framework for Implementing the Principles of the Circular Economy in Organizations-Guide; The British Standards Institution: London, UK, 2018.

8. Ribeiro, J.; Mendes, R.; Tavares, B.; Louro, C. Features of the incorporation of single and double based powders within emulsion explosives. J. Phys. Conf. Ser. 2014, 500, 19. [CrossRef]

9. Carapic, J.; Deschambault, E.J.; Holtom, P.; King, B. Handbook: A Practical Guide to Life-Cycle Management of Ammunition; Evoy, C.M., Ed.; Small Arms Survey, Graduate Institute of International and Development Studies: Geneva, Switzerland, 2018; ISBN 978-2-940548-49-1.

10. PRé Consultants; Version 8.0; SimaPro LCA Software: Amersfoort, The Netherlands, 2013.

11. Ferreira, C.; Freire, F.; Ribeiro, J. Life-cycle assessment of a civil explosive. J. Clean. Prod. 2015, 89, 159-164. [CrossRef]

12. ISO 14040, ISO 14040: Environmental Management_Life Cycle Assessment_Principles and Framework; International Organization for Standardization: Geneva, Switzerland, 2006.

13. Bohne, R.A.; Brattebø, H.; Bergsdal, H. Dynamic Eco-Efficiency Projections for Construction and Demolition Waste Recycling Strategies at the City Level. J. Ind. Ecol. 2008, 12, 52-68. [CrossRef]

14. Shen, L.; Worrell, E.; Patel, M.K. Comparing life cycle energy and GHG emissions of biobased PET, recycled PET, PLA, and man-made cellulosics. Biofuels Bioprod. Biorefin. 2012, 6, 625-639. [CrossRef]

15. Nuss, P.; Gardner, K.H.; Bringezu, S. Environmental Implications and Costs of Municipal Solid Waste-Derived Ethylene. J. Ind. Ecol. 2013, 17, 912-925. [CrossRef]

16. Nakatani, J. Life Cycle Analysis of Recycling: Mathematical and Graphical Frameworks. Sustainability 2014, 6, 6158-6169. [CrossRef]

17. Leinonen, I.; MacLeod, M.; Bell, J. Effects of Alternative Uses of Distillery By-Products on the Greenhouse Gas Emissions of Scottish Malt Whisky Production: A System Expansion Approach. Sustainability. 2018, 10, 1473. [CrossRef]

18. Clift, R.; Doig, A.; Finnveden, G. The Application of Life-Cycle Assessment to Integrated Solid Waste Management: Part 1-Methodology, Institution of Chemical Engineers. Trans. IChemE B 2000, 78, 278-287. [CrossRef]

19. European Commission—Joint Research Centre-Institute for Environment and Sustainability: International Reference Life Cycle Data System (ILCD). Handbook_General Guide for Life Cycle Assessment_Detailed Guidance, 1st ed.; EUR 24708 EN; Publications Office of the European Union: Luxembourg, 2010.

20. ISO 14044. ISO 14044: Environmental Management_Life Cycle Assessment-Requirements and Guidelines; International Standards Organization: Geneve, Switzerland, 2006.

21. Pennington, D.W.; Potting, J.; Finnveden, G.; Lindeijer, E.; Jolliet, O.; Rydberg, T.; Rebitzer, G. Life cycle assessment Part 2: Current impact assessment practice. Environ. Int. 2004, 30, 721-739. [CrossRef] [PubMed]

22. PRé. SimaPro Database Manual Methods Library, Report Version 2.7; PRé Consultants: PRé @: Amersfoort, The Netherlands, 2014; Available online: https:/ / support.simapro.com/articles/Manual/SimaPro-Methodsmanual (accessed on 19 February 2018).

23. Rosenbaum, K.; Bachmann, M.; Gold, S.; Huijbregts, J.; Jolliet, O.; Juraske, R.; Koehler, A.; Larsen, F.; MacLeod, M.; Margni, M.; et al. USEtox-The UNEP-SETAC toxicity model: Recommended characterisation factors for human toxicity and freshwater ecotoxicity in life cycle impact assessment. Int. J. Life Cycle Assess. 2008, 13, 532-546. [CrossRef]

24. Kim, J.; Yang, Y.; Bae, J.; Suh, S. The Importance of Normalization References in Interpreting Life Cycle Assessment Results. J.Ind. Ecol. 2013, 17, 385-395. [CrossRef]

25. Sleeswijk, A.W.; van Oers, L.F.C.M.; Guinée, J.B.; Struijs, J.; Huijbregts, M.A.J. Normalisation in product life cycle assessment: An LCA of the global and European economic systems in the year 2000. Sci. Total Environ. 2008, 390, 227-240. [CrossRef] [PubMed] 
26. Dones, R.; Bauer, C.; Bolliger, R.; Burger, B.; Faist Emmenegger, M.; Frischknecht, R.; Heck, T.; Jungbluth, N.; Röder, A.; Tuchschmid, M. Life Cycle Inventories of Energy Systems: Results for current systems in Switzerland and other UCTE Countries; Ecoinvet Report No. 5; Paul Scherrer Institut Villigen, Swiss Centre for Life Cycle Inventories: Dübendorf, Switzerland, 2007.

27. Garcia, R.; Marques, P.; Freire, F. Life-cycle assessment of electricity in Portugal. Appl. Energy 2014, 134, 563-572. [CrossRef]

28. Pauliuk, S. Critical appraisal of the circular economy standard BS 8001:2017 and a dashboard of quantitative system indicators for its implementation in organizations. Resour. Conserv. Recycl. 2018, 129, 81-92. [CrossRef]

29. Benini, L.; Mancini, L.; Sala, S.; Manfredi, S.; Schau, E.M.; Pant, R. Normalisation Method and Data for Environmental Footprints; European Commission, Joint Research Center, Institute for Environment and Sustainability, Publications Office of the European Union: Luxemburg, 2014; ISBN 978-92-79-40847-2.

(C) 2019 by the authors. Licensee MDPI, Basel, Switzerland. This article is an open access article distributed under the terms and conditions of the Creative Commons Attribution (CC BY) license (http://creativecommons.org/licenses/by/4.0/). 